\title{
Reducing the impact of adverse summer-autumn pasture conditions on livestock performance: results from farmer experience
}

\author{
R.W. WEBBY ${ }^{1}$, L.C.J. JOHNSTONE ${ }^{2}$ and R. SHERLOCK ${ }^{3}$ \\ ${ }^{1}$ AgResearch Ruakura, Private Bag 3123, Hamilton \\ ${ }^{2}$ Lockerbie, Matira Road, RD 2, Ngaruawahia \\ ${ }^{3} R D$ 2, Ngaruawahia \\ rex.webby@agresearch.co.nz
}

\begin{abstract}
A group of 12 farmers managing a total of 8845 ha in the West Waikato Region of the North Island, conducted a project to understand and overcome poor livestock performance during the summerautumn period. Pastures and livestock were monitored to measure the impact of the conditions. Metabolisable energy (ME) of pasture averaged 9.0, 9.8 and 9.3 mega joules per kg of dry matter over the 3 years of study and elevated levels of pasture toxins were consistently found from midJanuary to the end of May. To counter these conditions, farmers adopted varying strategies including pasture management and alternative feeding (silage and forage crops). A computerbased tool that enabled the user to make livestock feeding decisions based on the pasture cover, the ME of the pasture, and the quantity and ME of a feed supplement was developed. Farmers were able to reduce the proportion of damaged livers in lambs from 60 to $40 \%$ of the flock, which was against the district trend. When the right strategies were implemented, lamb and cattle liveweight gains increased from 52 to $146 \mathrm{~g}$ /day and 0.34 to $0.5 \mathrm{~kg} /$ day respectively. On average, ewe reproductive performance also improved during the period from 2.4 to $2.8 \%$ of lambs scanned $/ \mathrm{kg}$ ewe body weight. The project emphasised to farmers that their resident pastures did not meet the needs of a high performing livestock production system and that alternative feeding strategies were required if higher performance was to be achieved.
\end{abstract}

Keywords: Androvax, livestock feeding, metabolisable energy, pasture toxins, zinc

\section{Introduction}

The West Waikato region is an area of warm North Island hill country that stretches from Raglan in the south to Port Waikato in the north. Pasture growing conditions are favourable for two-thirds of the year (Webby unpublished). Between January and April, climatic conditions are usually adverse for pasture growth, resulting in inconsistent livestock performance both in terms of growing younger livestock and ewe reproductive performance. The quality and timing of livestock sales are variable and it is difficult for farmers to commit to more lucrative contract opportunities for marketing livestock. This constrains both farm profitability and the farmer's ability to meet customer needs. These conditions for livestock production are often referred to as 'autumn ill thrift' (Scales et al. 1981). They reflect both feed quality (Lambert \& Litherland 2000) and the effects of pasture toxins (Smith et al. 1991).

The work described in this paper comes from a project run by a group of Waikato farmers with the support of scientists from AgResearch's Whatawhata Research Centre. The project aim was to understand the relationships between feed quantity, the feed energy levels, potential livestock intake and pasture toxins. By understanding these relationships, the group believed they would be able to improve their livestock performance over the summer-autumn and thus be able to supply animals into higher value markets.

The West Waikato Group (Webby \& Paine 1997) was formed in 1989 around a monitor farm (Webby \& Sheath 1991). The monitor farm programme had helped the group identify a range of issues (Sheath et al. 1999) that affected farm performance. After the first monitor farm programme concluded, the group set itself in a new direction and focused more on the issue of farming successfully through the summer-autumn.

\section{Approach}

The project commenced in February 1998 and was completed in June 2000. Twelve farmers including two large "corporate type" farming enterprises and 10 owner-operated farms participated in the study group. The group farmed a total of 8845 effective ha carrying 100761 stock units (su). Table 1 summarises the physical characteristics of the farms involved.

At the start of the project, three livestock performance goals for January to April were set:

1. To lift average liveweight gains of finishing cattle from 0.1 to $0.6 \mathrm{~kg} /$ day. 
2. To lift average lamb liveweight gain to $200 \mathrm{~g} /$ day.

3. To increase ewe-scanning index to $3 \% / \mathrm{kg}$ ewe liveweight.

To achieve these targets, the project was broken down into four modules. Each module defined a set of tasks, so that each one contributed to and lead into the next.

\section{Module 1: Nutritional status of the current feed supply}

In completing this module, each farmer undertook a pasture measurement programme through the summer and autumn of each year. The quantity of pasture was measured (as pasture cover), mostly by the pasture height method (Webby \& Pengelly 1986). Whilst the pasture cover was being measured, a sample of pasture was plucked to the estimated grazing height of the livestock about to graze the paddock. The sample was sent away for analysis of metabolisable energy per $\mathrm{kg}$ of dry matter (ME) by near infra red spectrometer (NIRS) (Corson et al. 1999). A total of 311 samples were analysed.

\section{Module 2: Nutritional requirements of the livestock} Each farmer undertook to weigh monthly, the livestock grazing the pastures measured and sampled in module 1. Also, this module involved commissioning the development of a computer programme called "Quickfeed" (Woodward et al. 2000) that embraced both the quantity and nutritional status of the feed available and enabled the user to make improved feeding and grazing decisions.

\section{Module 3: Managing the nutritional requirements of the livestock}

For this module the whole farm system was analysed using Stockpol (Marshall et al. 1991) to establish how different aspects of livestock policy interacted and affected the way pastures could be managed. For each farmer, livestock management options were tested in Stockpol along with options to supply higher ME forage through silage making and forage cropping. These analyses provided a basis for farmers to put in place some of these options on their farms. Silage making became practice for eight of the farms in the group. The same eight farms sowed various forage crops. All eight farms used Pasja (Brassica sp.); three used chicory (Chicorium intybus) and only one farmer of the eight tried red clover (Trifolium pratense) and Sulla (Hedysarum coronarium). Silage was made from crops of Italian ryegrass (Lolium multiflorum), wheat (Triticum sp.), tall fescue (Festuca arundincea) and permanent pasture.

\section{Module 4: Response of livestock to nutritional management}

Mycotoxins in the pastures were measured and their association with livestock performance determined. The main toxin of concern was sporedesmin produced by Pithomyces chartarum, a fungus that causes the dilapidating disease known as facial eczema (FE) in livestock. The second mycotoxin, although of lesser concern and primarily associated with the dead content of the pasture, was zearalenone $(\mathrm{Z})$ produced by Fusaria fungi (Smith et al. 1991). To detect liver damage owing to sporesdesmin, serum gamma gultamyl tranferase (GGT) levels were measured in May each year (Towers \& Stratton 1978). A total of 1800 blood samples from ewe lambs were analysed for GGT and a total of 47 urine samples from 570 ewes were analysed for $\mathrm{Z}$ metabolites (Towers 1997). A sample of breeding ewes was weighed when the ram joined and on most farms, all ewes were pregnancy scanned about 70 days after joining. The immunoneutralisation vaccine Androvax (Smith 1985) was used by one farmer in the group throughout the course of the project. Three other farmers in the group had started to use the vaccine by the end of the project.

\section{Results and discussion}

\section{Modules}

Feed quality, as measured by the changes in the ME content of dry forage, declined from January to be lowest in February and March (average $(9.0 \mathrm{MJ} / \mathrm{kgDM})$ but recovered quickly after autumn rains to a more acceptable $10.9 \mathrm{MJ} / \mathrm{kgDM}$ ) by mid-May.

The Quickfeed model developed during the project provided farmers with a decision support tool that calculated livestock feeding requirements using both pasture cover and the ME value of the pasture. It also

Table $₫ 1$ Summary of farm physical characteristics on 1 June 1998 of a group of 12 farms in West Waikato.

\begin{tabular}{lrrccr}
\hline $\begin{array}{c}\text { Farm } \\
\text { Area } \\
\text { (ha) }\end{array}$ & $\begin{array}{c}\text { Total } \\
\text { su }\end{array}$ & $\begin{array}{c}\text { Ratio } \\
\text { Sheep: } \\
\text { Cattle: } \\
\text { Deer }\end{array}$ & $\begin{array}{c}\text { Lambing } \\
\%\end{array}$ & $\begin{array}{c}\text { Contour } \\
\text { Easy:Mod:Steep }\end{array}$ \\
\hline 1 & 495 & 5301 & $60: 40: 0$ & 111 & $10: 30: 60$ \\
2 & 370 & 3800 & $22: 78: 0$ & 118 & $40: 40: 20$ \\
3 & 240 & 2471 & $33: 67: 0$ & 95 & $20: 40: 30$ \\
4 & 1800 & 22500 & $51: 49: 0$ & 88 & $1: 50: 49$ \\
5 & 581 & 6950 & $64: 36: 0$ & 103 & $3: 37: 60$ \\
6 & 222 & 2100 & $38: 62: 0$ & 108 & $30: 50: 20$ \\
7 & 2770 & 30000 & $56: 44: 0$ & 115 & $15: 55: 30$ \\
8 & 414 & 5578 & $0: 100: 0$ & n/a & $35: 40: 25$ \\
9 & 280 & 3614 & $74: 26: 0$ & 100 & $25: 50: 25$ \\
10 & 630 & 6302 & $42: 58: 0$ & 98 & $5: 45: 50$ \\
11 & 750 & 8413 & $43: 51: 6$ & 100 & $13: 57: 30$ \\
12 & 293 & 3732 & $55: 45: 0$ & 117 & $30: 40: 30$ \\
\hline
\end{tabular}


allowed the user to introduce one feed supplement such as silage into the equation. At the end of the project, $80 \%$ of farmers were using, or had used, Quickfeed to guide grazing decisions. Farmers acknowledged that in addition to its value as a decision support tool, the model had also been useful in their understanding of the impact that feed quality (as ME) had on livestock performance.

The option of making silage in spring to feed livestock in summer and autumn was new to most farmers in the group. Of the eight that adopted silage making, only three had made it previously. Equally, only three farmers had sown forage crops in the past. The area in forage crops increased from 18 to 104 ha by the end of the project. The value of both the silage and forage crops was two-fold: Firstly with silage, the nutritive value improved by up to 1 and for the forage crops, up to $2 \mathrm{ME}$ units compared to the pasture available at the time; secondly, by providing feed free of both $\mathrm{FE}$ and $\mathrm{Z}$ toxins.

The summer-autumn of 1999 was one of the worst "FE seasons" on record in the region. However the GGT levels showed a reduction in the amount of liver damage that occurred during each year of the project. The number of lambs sampled with elevated GGT levels in 1999 was $33 \%$ less than in 1998 with a further $12.5 \%$ reduction in 2000 . Moving from $60 \%$ of lambs with an elevated GGT level to $40 \%$ is a significant achievement over 3 years in a row that favoured FE. This result was achieved against the district trends for FE particularly during the first 2 years, as shown in Table 2. This reduction in the proportion of lambs with liver damage is the combined result of a number of management changes. These included the use of the Time Capsule ${ }^{\mathrm{TM}}$, a zinc bolus to control FE (Munday et al. 1997), and the strategic use of crops. The combined results still reflect some farmers that did nothing in the group and who continued to have $70 \%$ of their lambs with liver damage. In the first year, only one farmer used boluses and had no elevated GGTs in the sample of lambs tested when all others tested in the group had significant numbers elevated. The use of boluses increased gradually within the group particularly in bull calves. Lambs benefited mostly by the increasing use of crops.

\section{Ewe performance}

The $\mathrm{Z}$ concentration in urine measured at mating time (Table 2) was elevated and did not change over the three seasons. As a general rule, breeding ewes were treated as lower priority compared with growing lambs and young cattle and therefore group farms were unable to provide ewes with high quality toxin-free forage during mating.

The one farmer who used Androvax across all ewes during all 3 years of the project was able to achieve consistently a lambing of $120 \%$ where prior to the use of Androvax lambing averaged 95\%. The Romney ewes averaged 48 to $50 \mathrm{~kg}$ at mating during the 3 years of the project. Using $2 \%$ of body weight as a guide to potential reproductive performance, the gain from the Androvax is considered to be around a 20 to $25 \%$ increase in lambing percentage.

The groups overall result from improved management of ewes at mating was a $16 \%$ increase in lambs scanned $/ \mathrm{kg}$ of liveweight at mating. This included a reduction in the number of ewes that were scanned with no lambs by $60 \%$ and an increase in the number of ewes scanned with twins by $28 \%$. The result represents a range of outcomes from do nothing with no

Table $\llbracket 2$ Facial eczema, Fusaria fungi toxins and related animal performance data by year. SEMs are in brackets.

\begin{tabular}{|c|c|c|c|}
\hline Description & 1998 & 1999 & 2000 \\
\hline Average pasture ME Jan-Feb (MJ/kg DM) & $9.0(0.16)$ & $9.8(0.13)$ & $9.3(0.20)$ \\
\hline Average pasture ME Mar to May (MJ/kg DM) & $10.1(0.09)$ & $10.4(0.29)$ & $10.1(-0.40)$ \\
\hline Average lamb gain Jan to May (g/day) & 52 & 52 & 146 \\
\hline Average R1yr bull gain Jan to May (kg/day) & 0.34 & 0.39 & 0.50 \\
\hline District average \% elevated GGT levels & $50 \%$ & $60 \%$ & $48 \%$ \\
\hline Within group \% samples with elevated GGT & $60 \%(5.4)$ & $45 \%(4.7)$ & $40 \%(7.4)$ \\
\hline End of season of elevated FE spore levels & $16 / 05 / 98$ & $30 / 05 / 99$ & $20 / 05 / 00$ \\
\hline Average ratio of $Z$ to urine creatinine $Z: 1(\mu \mathrm{mol} / \mathrm{mol})$. Note $>12.5: 1$ is toxic (Towers 1997$)$ & $27(2.1)$ & $29(3.7)$ & $28(5.5)$ \\
\hline
\end{tabular}

Table $\llbracket 3$ Average ewe reproductive performance during the project showing results at pregnancy scanning, liveweight at mating and the index of lambs scanned/kg ewe liveweight at mating. SEMs are in brackets.

\begin{tabular}{llllll}
\hline Year & $\%$ Drys & \% Singles & \% Twins & Live wt $(\mathrm{kg})$ & Scan \% \\
\hline 1998 & $9(2.0)$ & $52(4.2)$ & $39(4.2)$ & $52(1.1)$ & $131(5.5)$ \\
1999 & $8(0.8)$ & $50(3.5)$ & $41(3.1)$ & $52(1.9)$ & $135(4.5)$ \\
2000 & $5(0.2)$ & $45(13)$ & $50(13)$ & $53(1.6)$ & $146(5.5)$ \\
\hline
\end{tabular}


improvement to a well-managed strategy with a scanning index of $3.2 \%$. Table 3 summarises these results.

\section{Financial results}

The impact of the project on the financial performance of the farms involved was confounded by a number of factors. Although the three critical summer-autumn periods were similar climatically, the average rainfall during the 3 years prior to the start of the project was $423 \mathrm{~mm}$ and during the project $226 \mathrm{~mm}$. This meant that compared to earlier years, fewer stock were being carried through and the benefits of improved livestock performance in summer-autumn were nullified by the effect of lower numbers in the overall farm enterprise. The dynamic nature of farming also influenced the results. Some farmers increased the size of their farms and others made major changes in livestock policy during the project. Table 4 shows details of the financial returns. On average, gross farm income increased by $10 \%$ and income $/ \mathrm{kg}$ of product increased by $20 \%$ during the project. Although this may reflect more product being supplied into a higher value markets, the biggest gains were from overall increases in product prices. Expenditure in the first year was lower than in the second and third years of the project so that the gain in net income was relative small at $6 \%$.

Table $\llbracket 4$ Average income, expenditure and production/ha during the project. SEMs are in brackets.

\begin{tabular}{lccc}
\hline Year ending 30 June & 1998 & 1999 & 2000 \\
\hline Gross income/ha (\$) & $501(72)$ & $442(60)$ & $547(73)$ \\
Expenditure/ha (\$) & $241(13)$ & $267(20)$ & $270(25)$ \\
Net income/ha (\$) & $261(71)$ & $175(54)$ & $277(59)$ \\
Gross income/kg product (\$) & $2.19(0.17)$ & $2.22(0.15)$ & $2.64(0.20)$ \\
Expenditure/kg product (\$) & $1.10(0.14)$ & $1.39(0.16)$ & $1.37(0.12)$ \\
Net return/kg product (\$) & $1.09(0.16)$ & $0.83(0.15)$ & $1.28(0.18)$ \\
Product sold (kg/ha) & $229(38)$ & $199(33)$ & $207(30)$ \\
\hline
\end{tabular}

\section{Summary}

The actual levels of performance achieved as a result of the project were a little short of the targets set at the start but showed good progress under adverse conditions. For the cattle, a weight gain of $0.5 \mathrm{~kg} / \mathrm{day}$ was achieved on average, against the target of $0.6 \mathrm{~kg} /$ day (Table 2). For lambs, the actual average daily weight gain was 146 (vs $200 \mathrm{~g}$ /day target) (Table 2). For the ewe-scanning index, $2.8 \% / \mathrm{kg}$ was achieved against the target of $3 \% / \mathrm{kg}$ of ewe liveweight (Table 3 ). As a result of the project, each farmer adopted at least one strategy to improve their farms' performance in summer-autumn. Although each strategy carried out had its own benefits, the greatest potential gains remain with the adoption of a whole range of strategies.
However, dry seasons and low product prices constrained farmers in the extent to which they able move initially to adopt and apply these strategies which included:

- Profitable livestock systems to utilise feed and manage feed quality.

- Crops to supply high-quality toxin-free forage.

- Silage to supplement feeding at critical times and to utilise surplus spring pasture production.

- Androvax to boost ewe fertility when suppressed by harsh conditions.

- Zinc boluses to protect susceptible livestock from FE.

- A computer model to improve decision making and understanding of the relationships between pasture cover, the ME of the pasture and the liveweight gain of the animal.

The farmers in this project set out to overcome the adverse effects of a time of year that had a depressing effect on their farm profitability. Typically the climate produced not only the usual adverse summer-autumns but also a sequence of drier-than-normal seasons that increased this adversity providing the ultimate test for what was attempted during the course of the project. Experience and knowledge were gained from the project on how to monitor and overcome the problem. Understanding the limitations of their pastures as a feed source in summer-autumn has been an important realisation for farmers who are now better positioned to continue to improve and produce a product to meet their customers needs.

\section{ACKNOWLEDGEMENTS}

The support of this project by Technology New Zealand and Ballance Agri-Nutrients is gratefully acknowledged.

\section{REFERENCES}

Corson, D.C.; Waghorn, G.C.; Ulyatt, M.J.; Lee, J. 1999. NIRS: Forage analysis and livestock feeding. Proceedings of the New Zealand Grassland Association 61: 127-132.

Lambert, M.G.; Litherland, A.J. 2000. A practitioner's guide to feed quality. Proceedings of the New Zealand Grassland Association 62: 111-115.

Marshall, P.R.; McCall, D.G.; Johns, K.L. 1991. Stockpol: A decision support model for livestock farms. Proceedings of the New Zealand Grassland Association 53: 137-140. 
Munday, R.; Thompson, A.M.; Fowke, E.A.; Wesselink, C.; Smith, B.L.; Towers, N.R.; O'Donnell, K.; McDonald, R.M.; Stirneman, M.; Ford, A.J. 1997. A zinc-containing intraruminal device for facial eczema control in lambs. New Zealand Veterinary Journal 45: 93-98.

Scales, G.H.; Moss, R.A.; Burton R.N. 1981. Summer ill-thrift in lambs. Proceedings of the New Zealand Society of Animal Production 41: 112-116.

Sheath, G.W.; Webby, R.W.; Keeling, P.; Thomson, R.D.; Page, C.R.; Burton, .G.T. 1999. The results and success factors of nine group farm monitoring programmes. Proceedings of the New Zealand Society of Animal Production 59: 87-90.

Smith, J.F. 1985. Immunisation of ewes against steroids: A review. Proceedings of the New Zealand Society of Animal Production 45: 171-177.

Smith, J.F.; di Menna, M.; Towers, N.; Sprosen, J. 1991. Zearalenone and Fusarium - What and where it is and its effects on reproductive performance in sheep. Proceedings of the Ruakura Farmers Conference 43: 194-198.

Towers, N.R.; Stratton, G.C. 1978. Serum gammaglutamyl transferase as a measure of sporidesmin induced liver damage in sheep. New Zealand Veterinary Journal 26: 109-112.
Towers, N. 1997. Pasture as a source of Fusarium toxins in New Zealand. pp. 15-19. In: $19^{\text {th }}$ Mycotoxin workshop. Eds. Martlbauer, Erwin, Usleber, Ewald. Institut fur Hygiene und Technologie der Lebensmittel tierischen Ursprungs Tierarztliche Fakultat, Ludwig-MaximiliansUniversitat Munchen. Munich.

Webby, R.W.; Sheath, G.W. 1991. Group monitoring, a basis for decision making and technology transfer on sheep and beef farms. Proceedings of the New Zealand Grassland Association 53: 13-16.

Webby, R.W.; Paine, M.S. 1997. Farmer groups: a measure of their effectiveness. Proceedings of the New Zealand Society of Animal Production 57: 109-111.

Webby, R.W.; Pengelly, W.J. 1986. The use of pasture height as a predictor of feed level in North Island hill country. Proceedings of the New Zealand Grassland Association 47: 249-253.

Woodward, S.J.R.; Johnstone, L.J.C.; Webby, R.W. 2000. A decision tool for calculating herbage mass and metabolisable energy requirements of growing cattle and sheep. Proceedings of the New Zealand Grassland Association 62: 13-18. 